\section{Velskrevet og etterlengtet lærebok i psykoonkologi}

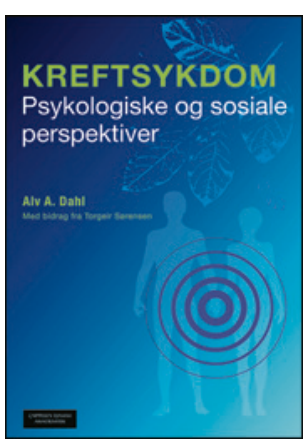

\section{Alv A. Dahl}

\section{Kreftsykdom}

Psykologiske og sosiale perspektiver. 385 s, tab, ill. Oslo: Cappelen Damm Akademisk, 2016. Pris NOK 489

ISBN 978-82-02-47431-7

Denne læreboken er aktuell i bachelor- og masterutdanningen i sykepleie og for alle som arbeider med kreftpasienter og kreftoverlevere.

Det er 17 kapitler og en innholdsfortegnelse som gjør det enkelt å bruke den som både lærebok og oppslagsverk. Språket er lett forståelig og tydelig, underbygd av gode illustrasjoner og figurer.

Særlig positivt er det med sykehistoriene som går som en rød tråd gjennom kapitlene. Dette konkretiserer fagstoffet på en pedagogisk elegant måte. Etter hvert kapittel oppsummeres de sentrale punktene i innholdet.

Kapitlet om kommunikasjon kommer tidlig og gir dette temaet en like sentral plass som det har i møtet med kreftpasienter i en klinisk hverdag. Her får leserne tydelige råd om hva som er riktig og gal fremgangsmåte i samtalen med pasientene.

Videre tar forfatteren for seg blant annet pasienters sårbarhet, personlighet, tilpasningsforstyrrelser, søvnproblemer, arbeidsliv, seksualitet, sorgreaksjoner og åndelighet. Han har bred og solid kunnskap så vel som erfaring i alle disse temaene, og det er gjennomgående henvisninger til studier, artikler, lærebøker samt skjønnlitteratur og film.

Nødvendig kunnskap innen psykoonkologi har for undertegnede til nå vært tilgjengelig svært så fragmentert, og mye kunnskap er blitt ervervet gjennom egne erfaringer. Det er derfor gledelig at vi nå har tilgang på denne boken, som gir oss en dypere forståelse for hva vi møter, hvordan vi skal kartlegge det nærmere samt hvordan vi kan ha en terapeutisk tilnærming til psykoonkologiske utfordringer.

\section{Ronny Dalene}

Overlege, Palliativ enhet

Sykehuset Telemark

\section{Kan vi leger gjøre feil?}

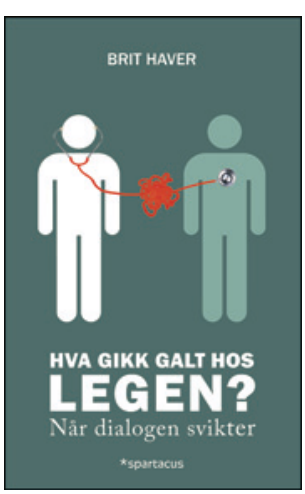

Brit Haver

Hva gikk galt hos legen?

Når dialogen svikter. 212 s. Oslo: Spartacus

forlag, 2016. Pris NOK 349

ISBN 978-82-430-1000-0

Ideen til denne boken oppsto på en Hawaii-restaurant hvor flere kvinnelige leger delte sine problematiske opplevelser som pasient. De spurte seg etter hvert som historiene kom frem: «Kunne dette være mulig?» Forfatteren ble inspirert til å samle pasienters erfaringer med sine leger. Gjennom annonser i dagspressen kom hun i kontakt med mange som hun enten intervjuet eller oppfordret til å sende en skriftlig versjon av opplevelsen. De beretningene som handlet om sviktende kommunikasjon mellom pasient og lege, er referert i boken, med forfatterens kommentarer til hver enkelt.

Det er 18 tematiske kapitler, med emner som spenner over temaer som Mangelfull kontakt, Uhøflige leger og Når legen overskrider etiske grenser. Forfatteren har fortjenestfullt satt søkelyset på et ubehagelig fenomen innen legestanden. Hun spør: «Hvordan kan det ha seg at leger ikke alltid behersker en så grunnleggende forutsetning for legevirksomhet, nemlig samtalen med pasienten?» Hun antyder følgende forklaring: «Konsultasjonsteknikker har i relativt liten grad blitt vektlagt under utdannelsen av leger, sammenlignet med «ren» medisinsk kunnskap.»

Er det en plausibel forklaring? Forskning på norske medisinere ved studie- og turnusslutt viser at disse har et klart forbedringspotensial når det gjelder ferdigheter i klinisk kommunikasjon. Dette tyder på at forfatteren er inne på en forklaring som det må forskes videre på og som bør gi kunnskapsbaserte signaler til ansvarlige instanser om utforming av utdanningsprogrammene ved våre fire medisinske fakulteter.

Andre faktorer, ikke minst legens personlighet, spiller selvfølgelig en viktig rolle i denne sammenheng, men uansett har forfatteren med denne boken satt et viktig tema på dagsordenen - med det mål for øye at dialogen mellom pasient og lege ikke skal svikte.

Slike ferdigheter kan imidlertid ikke tilegnes kun gjennom lesing, men også ved øving under forhold så nær opptil den kliniske situasjonen som mulig - som grunnlag for en emosjonell læringsprosess. Denne er vel så viktig som den teoretiske. Det krever små undervisningsgrupper der deltagerne kan bli trygge nok til egeneksponering. Erfaringer med bruk av skuespillere som kan instrueres i pasientrolleutformingen, er positive ved de norske lærestedene - ved nettopp å fremme emosjonell læring.

For all klinisk virksomhet gjelder regelen: Pasienten er fasiten. Det er ikke dermed sagt at «pasienten har fasiten». I denne boken er legenes stemme ikke kommet med. Det fratar den likevel ikke legitimitet og stor nytteverdi for både den primære målgruppen, som er medisinstudenter, og for ferdige leger og andre faggrupper i helsevesenet.

Tore Gude

Professor emeritus, Avdeling for medisinsk atferdsvitenskap Universitetet i Oslo 